\title{
Gender quotas, gender mainstreaming and gender relations in politics
}

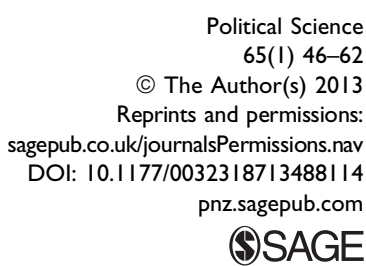

Political Science 65 (I) 46-62

(C) The Author(s) 2013 agepub.co.uk/journalsPermissions.nav pnzsagepub.com (S)AGE

\section{Petra Meier and Emanuela Lombardo}

\begin{abstract}
This article seeks to reintroduce discussions on gender relations in politics back into scholarly and political debate. Many countries have adopted gender quotas, but it is unclear whether their implementation has meaningfully changed the prevalent inequalities governing gender relations in politics. This article considers whether the implementation of gender quotas could promote change, and assesses this change with reference to five criteria formerly used to assess the strategy of gender mainstreaming. These are a shift towards a more comprehensive concept of gender equality; the incorporation of a gender perspective intersected with other inequalities in mainstream politics; equal political representation; organizational changes in selection and recruitment mechanisms as well as the functioning of politics; and, finally, the displacement of hierarchies, and the empowerment of subjects. Reflection on and empirical illustrations of gender quotas with regard to these criteria reveal a mixed picture, demonstrating the need to reintroduce discussions about gender equality within politics back into gender quota debates. This discussion will not focus on the legitimacy of or need for gender quotas, but on how their implementation can contribute to the improvement of gender relations in politics beyond a quantitative sense. Approaching gender quotas through the use of criteria devised for assessing the gender mainstreaming strategy is helpful in exploring the potential of gender quotas in the transformation of gender relations.
\end{abstract}

\section{Keywords}

gender equality, gender equality in politics, gender mainstreaming, gender quotas, intersectionality

\section{Corresponding author:}

Petra Meier, Universiteit Antwerpen, Faculteit PSW, Sint Jacobstraat 2, 2000 Antwerp, Belgium.

Email: petra.meier@ua.ac.be 


\section{Introduction}

In the 1990 s there was ample debate - both political ${ }^{1}$ and academic $^{2}$ - on the pros and cons of gender quotas. More women in legislative politics were needed and gender quotas were an important tool in facilitating their access to political decision-making, but such measures were also considered to be a risky undertaking. However, many of the political and academic debates of the 1990s have faded away, perhaps because gender quotas have become a common policy tool, and the number of women in political decision-making has increased considerably. ${ }^{3}$

In addition to addressing causes for the adoption of gender quotas, current debates address the effectiveness of such tools in increasing the number of women in legislative politics, ${ }^{4}$

1 See the 1992 Declaration of Athens, the 1995 Beijing Platform of Action and the 1996 Charter of Rome.

2 Kathrin Arioli, Quoten und Gleichstellung von Frau und Mann (Basel: Helbing \& Lichtenhahn Verlag, 1996); Kathrin Arioli, Frauenförderung durch Quoten (Basel: Helbing \& Lichtenhahn Verlag, 1997); Ruth Lister, Citizenship: Feminist Perspectives (London: Macmillan, 1997); Petra Meier, 'On the Theoretical Acknowledgement of Diversity in Representation', Res Publica, Vol. 43, No. 4 (2001), pp. 551-570; Anne Phillips, The Politics of Presence (Oxford: Clarendon Press, 1995); Marian Sawer, 'Parliamentary Representation of Women: From Discourses of Justice to Strategies of Accountability', International Political Science Review, vol. 21 (2000), pp. 361-380; Judith Squires, 'Quotas for Women: Fair Representation?', Parliamentary Affairs, Vol. 49, No. 1 (1997), pp. 71-88; Rian Voet, Feminism and Citizenship (London: SAGE, 1998); Iris M. Young, Inclusion and Democracy (Oxford: Oxford University Press, 2000).

3 Drude Dahlerup (ed.), Women, Quotas and Politics (New York: Routledge, 2006); Mona L. Krook, Quotas for Women in Politics: Gender and Candidate Selection Reform Worldwide (Oxford: Oxford University Press, 2009).

4 See, for instance, Clara Araújo and Ana Isabel García, 'Latin America: The Experience and the Impact of Quotas in Latin America', in Dahlerup, Women, Quotas and Politics; Mala N. Htun and Mark P. Jones, 'Engendering the Right to Participate in Decision-Making: Electoral Quotas and Women's Leadership in Latin America', in Nikki Craske and Maxime Molyneux (eds), Gender and the Politics of Rights and Democracy in Latin America (New York: Palgrave, 2002); Mark P. Jones, 'Electoral Institutions, Social Cleavages, and Candidate Competition in Presidential Elections', Electoral Studies, Vol. 23, No. 2 (2004), pp. 73-106; Mark P. Jones, 'Gender Quotas, Electoral Laws, and the Election of Women Evidence from the Latin American Vanguard', Comparative Political Studies, Vol. 42, No. 1 (2009), pp. 56-81; Pamela Paxton, Melanie M. Hughes and Matthew A. Painter II, 'Growth in Women's Political Representation: A Longitudinal Exploration of Democracy, Electoral System and Gender Quotas', European Journal of Political Research, Vol. 49, No. 1 (2010), pp. 25-52; Gregory D. Schmidt and Kyle L. Saunders, 'Effective Quotas, Relative Party Magnitude, and the Success of Female Candidates', Comparative Political Studies, Vol. 37, No. 6 (2004), pp. 704-24; Lesley Schwindt-Bayer, 'Making Quotas Work: The Effect of Gender Quota Laws on the Election of Women', Legislative Studies Quarterly, Vol. 34, No. 1 (2009), pp. 5-28; Manon Tremblay (ed.), Women and Legislative Representation: Electoral Systems, Political Parties and Sex Quotas (New York: Palgrave Macmillan, 2012); Aili M. Tripp and Alice Kang, 'The Global Impact of Quotas: On the Fast Track 
and in improving their substantive representation. ${ }^{5}$ While the former debates look at more technical aspects of gender quotas - under what conditions they are adopted, how they work - the issue of substantive representation shifts the focus to the representation of citizens and their relations with representatives. Recently, literature has begun to explore the broader symbolic effects of gender quotas, such as the extent to which they increase voters' confidence in political systems. ${ }^{6}$ In comparison, the debates of the 1990s focused more on the gendered character of relations within legislative politics. The 'justice or democracy' debate, for instance, referred to gendered thresholds in politics; opinions differed on whether the under-representation of women was due to badly functioning democratic institutions or to failing normative foundations of postmodern Western democracies. It was argued that once discriminating mechanisms were removed, women would participate in politics in greater numbers. Their absence in large numbers thus points at the continued existence of gendered thresholds, making access to politics more difficult for women than for their male colleagues. Similarly, the argument that the presence of more women in politics leads to better politics and policies suggests masculine practices in politics. ${ }^{7}$

This article aims to bring the issue of gender relations in politics back into scholarly and political debates, and to broaden it to include gender equality in politics beyond numbers. This is for two reasons. First, the greater number of women in politics is no guarantee that gender relations more broadly have improved as well. Second, the prevalence of gender quotas begs a debate on their potential to transform gender relations within politics. Evidence shows that the legislative environment remains predominantly male and that women tend to adapt to this environment. ${ }^{8}$

Gender quotas are designed as a tool to address the under-representation of women and to improve their descriptive representation. However, their potential to influence gender relations within the political arena itself must be assessed beyond their ability to affect the substantive and symbolic representation of women. Going beyond the debate on numerical representation necessitates examining the potential for gender

to Increased Female Representation', Comparative Political Studies, Vol. 41, No. 3 (2008), pp. $338-361$.

5 See, for instance, Sarah Childs, Women in British Party Politics: Descriptive, Substantive and Symbolic Representation (Oxford: Routledge, 2008); Susan Franceschet and Jennifer M. Piscopo, 'Gender Quotas and Women's Substantive Representation: Lessons from Argentina', Politics \& Gender, Vol. 3, No. 4 (2008), pp. 393-425; Yvonne Galligan and Manon Tremblay (eds), Sharing Power: Women, Parliament, Democracy (Aldershot: Ashgate, 2005); Jane Mansbridge, 'Quota Problems: Combating the Dangers of Essentialism', Politics \& Gender, Vol. 1, No. 4 (2005), pp. 622-638.

6 Susan Franceschet, Mona L. Krook and Jennifer Piscopo (eds), The Impact of Gender Quotas (New York: Oxford University Press, 2012).

7 Meier, 'On the Theoretical Acknowledgement of Diversity in Representation', pp. 551-570.

8 Karen Celis and Bram Wauters, 'Pinning the Butterfly: Women, Blue-Collar and Ethnic Minority MPs vis-à-vis Parliamentary Norms and the Parliamentary Role of the Group Representative', Journal of Legislative Studies, Vol. 16 (2010), pp. 380-393; Nira Puwar, Space Invaders. Race, Gender and Bodies Out of Place (Oxford: Berg, 2008). 
equality policies, such as gender quotas, to promote transformation in gender roles in political decision-making.

It is here that the strategy of gender mainstreaming becomes relevant. Gender mainstreaming is a transversal approach to promoting gender equality, whereby gender issues should be tackled through all government policy areas, and not only those earmarked for the promotion of gender equality. It therefore opens the possibility of 'setting the agenda' from a gender perspective, in order to transform all policy areas, actors and processes, and thereby achieving a more gender-equal society. ${ }^{9}$ Since the fourth UN World Conference on Women in Beijing in 1995, many countries have embraced gender mainstreaming as a strategy to promote gender equality. Although studies show that the implementation of gender mainstreaming can be problematic and unsuccessful, ${ }^{10}$ they also reveal the strategy's potential to enhance the gender equality of organizations through the empowerment of subjects, the training of civil servants and the forging of strategic alliances. ${ }^{11}$ At first glance, gender quotas and gender mainstreaming seem to be separate tools to improve gender equality, and they tend to be presented as such: for example, gender quotas are thought to focus on women, while gender mainstreaming focuses on gender. While the former seeks to bring women into the process of political decision-making, the latter seeks to bring gender into public policies. Likewise, gender quotas are heavily contested, while gender mainstreaming is more easily adopted despite facing strong opposition at the implementation stage. ${ }^{12}$ However, the two strategies share much in common. Squires argues that despite conceptual tensions between the two, substantial complementarities remain between gender quotas and gender mainstreaming with respect to a similar

9 R. Jahan, The Elusive Agenda: Mainstreaming Women in Development (London: Zed Books, 1995).

10 Yvonne Benschop and Mieke Verloo, 'Sisyphus' Sisters: Can Gender Mainstreaming Escape the Genderedness of Organizations?', Journal of Gender Studies, Vol.15 (2006), pp. 19-33; Fiona Beveridge, Sue Nott and Kylie Stephen, 'Mainstreaming and the Engendering of Policy-Making: A Means to an End', Journal of European Public Policy, Vol. 7, No. 3 (2000), pp. 385-405; Cinnamon Booth and Chris Bennett, 'Gender Mainstreaming in the European Union: Towards a New Conception and Practice of Equal Opportunities?', European Journal of Women's Studies, Vol. 9, No. 4 (2002), pp. 430-446; Sonia Mazey, 'Introduction: Integrating Gender - Intellectual and "Real World" Mainstreaming', Journal of European Public Policy, Vol. 7, No. 3 (2000), pp. 333-345; Teresa Rees, 'Reflections on the Uneven Development of Gender Mainstreaming in Europe', International Feminist Journal of Politics, Vol. 4, No. 4 (2005), pp. 555-574.

11 Rosalynd Eyben, 'Subversively Accommodating: Feminist Bureaucrats and Gender Mainstreaming', IDS Bulletin, Vol. 41, No. 2 (2010), pp. 54-61; Jacqui True, 'Gender Mainstreaming in International Institutions', in Laura J. Shepherd (ed.), Gender Matters in Global Politics (New York: Routledge, 2009); Tanhya Barnett-Donaghy, 'Applications of Gender Mainstreaming in Australia and Northern Ireland', International Political Science Review, Vol. 25, No. 4 (2004), pp. 393-410.

12 Lut Mergaert, 'The Reality of Gender Mainstreaming Implementation: The Case of the EU Research Policy' (doctoral dissertation, Radboud Universiteit, Nijmegen, 2012). 
final goal. ${ }^{13}$ Elsewhere, gender quotas and gender mainstreaming have been described as part of a dual strategy to achieve gender equality. ${ }^{14}$

In this article we argue that gender quotas and gender mainstreaming are more than a dual strategy. Gender quotas can, under specific circumstances, be a good - or even the best - practice of gender mainstreaming. To this end, gender quotas need to build upon a number of quality criteria that have been identified for gender mainstreaming. ${ }^{15}$ These criteria encompass five shifts in the policy-making sphere that a gender mainstreaming strategy should provoke to realize its transformative potential. We investigate how gender quotas relate to gender mainstreaming, and hence how a gender mainstreaming perspective can contribute to the adoption of a broad approach to gender (in)equality in politics. We then suggest that the application of such an approach to gender quotas can strengthen them as an instrument in the transformation of gender relations in politics. The conceptual exploration of the relationship between the two gender equality strategies undertaken in this article thus contributes to the reintroduction of gender relations in politics into scholarly and political debates.

We first briefly discuss the potential shifts that a gender mainstreaming approach may initiate, and we then analyse the extent to which gender quotas may provoke similar shifts. This conceptualization draws on empirical studies of gender quotas debated in the literature, as well as empirical work conducted in northern, east-central and southern Europe, to illustrate the reflection developed within the framework of the European research project on Mainstreaming Gender Equality in Europe (MAGEEQ). ${ }^{16}$

\section{Gender mainstreaming quality shifts}

To assess the extent to which gender quotas could promote a broad approach to gender (in)equality, we consider gender quotas in relation to a number of shifts that have been devised with respect to gender mainstreaming. ${ }^{17}$

The first is a shift in concepts underlying the policy-making process. Gender mainstreaming implies a shift towards a broader concept of gender equality that explicitly

13 Judith Squires, The New Politics of Gender Equality (Houndmills: Palgrave Macmillan, 2007), pp. 85-86.

14 Council of Europe, Conceptual Framework, Methodology and Presentation of Good Practices: Final Report of Activities of the Group of Specialists on Mainstreaming (Strasbourg: Council of Europe, 1998).

15 Emanuela Lombardo, 'Integrating or Setting the Agenda? Gender Mainstreaming in the European Constitution-Making Process', Social Politics, Vol. 12, No. 3 (2005), pp. 412-432.

16 European Union FP5 research project 'Policy Frames and Implementation Problems: The Case of Gender Mainstreaming', available at: www.mageeq.net. See also Mieke Verloo (ed.), Multiple Meanings of Gender Equality: A Critical Frame Analysis of Gender Policies in Europe (Budapest: CPS Books, 2007).

17 Lombardo, 'Integrating or Setting the Agenda?; Emanuela Lombardo and Petra Meier, 'Gender Mainstreaming in the EU: Incorporating a Feminist Reading?', European Journal of Women's Studies, Vol. 13, No. 2 (2006), pp. 151-166. 
addresses the patriarchal system by tackling the multiple interconnected factors that create unequal relations between the sexes in fields such as family, work, politics, sexuality, culture and violence. ${ }^{18}$ This promotes a shift towards a concept of gender equality that acknowledges the intersection of inequalities. ${ }^{19}$ A focus on gender calls for the inclusion of both men and women in the conceptualization of a given policy problem and its potential solutions, so that existing male privileges are challenged. A focus on intersectionality articulates how race, ethnicity, class or other inequalities may interact with gender and generate privileges and exclusions for different subjects. For example, if the aim of gender quotas is to promote the representation of women as a group, an intersectional perspective to quotas may also imply an attempt to promote less privileged women within the group. We wish to question the extent to which gender quotas broaden the concept of gender equality and its intersections within politics.

A second shift is the incorporation of a gender perspective, intersected with other inequalities, into the mainstream political agenda. This requires evidence that the mainstream political agenda has been reoriented by the articulation of policy ends and means from a gender perspective, prioritizing gender equality over competing objectives. ${ }^{20}$ Here we wish to explore several questions. First, to what extent did debates on gender quotas put the issue of gender equality centre-stage within the political arena? Second, how was this achieved?

A third shift recommends equal political representation of women and men as a means to ensure that women will, at least numerically, be part of the mainstream. This shift specifically considers the descriptive representation of women: given that gender quotas are understood as a tool for the achievement of gender balance, has their implementation increased the number of women in politics? This question is important in that gender quotas may affect the input side of electoral policies, ameliorating matters such as the number of female candidates, without necessarily changing any outputs, such as the proportion of women elected. In such outcomes, gender quotas serve as mere cosmetic operations.

A fourth quality shift concerns the institutional and organizational cultures of political decision-making, and requires changes to policy processes, mechanisms and actors. This includes acquisition of the necessary gender expertise, including knowledge of the mechanisms causing and reproducing gender inequality, as well as means to overcome them. By focusing on numbers, gender quotas tackle neither the causes of women's under-representation in politics (why they do not enter politics to the same extent as

18 Sylvia Walby, Theorizing Patriarchy (Oxford: Blackwell, 1990).

19 K. W. Crenshaw, 'Mapping the Margins: Intersectionality, Identity Politics, and Violence against Women of Color', Stanford Law Review, Vol. 43, No. 6 (1991), pp. 1241-1299; L. McCall, 'The Complexity of Intersectionality', Signs. Journal of Women in Culture and Society, Vol. 30, No. 3 (2005), pp. 1771-1800; Ange-Marie Hancock, 'When Multiplication Doesn't Equal Quick Addition: Examining Intersectionality as a Research Paradigm', Perspectives on Politics, Vol. 5, No. 1 (2007), pp. 63-79; Sylvia Walby, Globalization and Inequalities: Complexity and Contested Modernities (London: SAGE, 2009).

Jahan, The Elusive Agenda. 
men) nor the consequences of the political arena's masculine rules and practices for female politicians once they get there. The fourth shift tackles both such causes and consequences. This shift directly appeals to efforts which go beyond the mere improvement of numbers, and it does so in two respects.

First, in order to go beyond the numbers, gender quotas must address the failure of electoral systems to promote the candidacy and election of female candidates. This requires public knowledge and rearticulation of the mechanisms within electoral systems causing and reproducing gender inequality. Second, the fourth shift necessitates looking into policy processes and mechanisms embedded in the political arena, and what they mean for female politicians compared to their male counterparts. Can the implementation of gender quotas lead to an adjustment of structures, procedures and tools within the political arena whenever these contain a gender bias?

A fifth shift requires gender mainstreaming to be transformative through the creation of spaces where gender concepts and strategies may be continuously contested; this enables the displacement of existing hierarchies, the promotion of diversity and the empowerment of subjects. $^{21}$ The fifth shift thus involves greater civil society participation. It aligns with the feminist conception of 'velvet triangles' of empowerment, which link formal and informal aspects of political action by connecting actors from women's policy agencies, politicians and feminist civil society actors. ${ }^{22}$ This shift questions the extent to which gender quotas create spaces for gender contestation and women's empowerment as well as the aforementioned 'velvet triangles' within the political arena.

A further issue to consider in all the aforementioned criteria is the idea of incremental change, meaning that change should be constantly assessed with regard to the status quo ante. ${ }^{23}$ For example the introduction of a 40 per cent gender quota in a context where no similar provisions were formerly in place can be considered an important quality change. In a context where women's political representation already reaches such a percentage, however, the same measure may be considered a minimal threshold.

Pursuing these five qualitative shifts would ensure that gender quotas focus on transforming persistent gender inequalities in politics, rather than only serving as a means of increasing numbers of women. In this sense, the preceding conceptual exercise gives the discussion on gender quotas a broader scope, which includes issues beyond

21 Judith Squires, 'Is Mainstreaming Transformative? Theorizing Mainstreaming in the Context of Diversity and Deliberation', Social Politics, Vol. 12, No. 3 (2005), pp. 366-388; Mieke Verloo, 'Reflections on the Concept and Practice of the Council of Europe Approach to Gender Mainstreaming', Social Politics, Vol. 12, No. 3 (2005), pp. 344-365.

22 Geertje Lycklama à Nijeholt et al. (eds), Women's Movements and Public Policy in Europe, Latin America and the Caribbean (New York: Garland, 1998); Alison Woodward, 'Building Velvet Triangles: Gender and Informal Governance', in Thomas Christiansen and Simona Piattoni (eds), Informal Governance in the European Union (Cheltenham: Edward Elgar, 2004).

23 Andrea Krizsan and Emanuela Lombardo 'The Quality of Gender Equality Policies. A Discursive Approach', European Journal of Women's Studies, Vol. 20, No. 1 (2013), pp. $77-92$. 
numerical representation. In the following sections we address the relationship between the use of gender quotas and the different shifts pursued by gender mainstreaming.

\section{Can the use of gender quotas broaden the concept of gender equality and its intersections?}

The wider framing of policy debates on gender quotas can help to situate them within a broader understanding of gender and other inequalities, or even to limit or 'twist' the scope of such debates. However, research by Lombardo et al. on the EU and six of its member states (Austria, the Netherlands, Hungary, Slovenia, Greece and Spain) revealed that policy discourses on gender quotas still tend to focus predominantly on the quantitative elements of female representation. ${ }^{24}$ Such research typically assumes binary positions against or in favour of gender quotas, and this tends to obscure broader issues of gender inequality such as male domination in politics, the traditional gender division of labour, and patriarchal structures that preserve barriers to women's representation. By not directly calling upon men's involvement in the process of transformation, and placing the burden for change on women's shoulders, present policy discourses on gender inequality in politics pose few challenges to male political power.

Nonetheless, adoption of gender quotas has in many cases reframed the concept of gender equality away from a formalistic interpretation as equality before the law, and towards equality in opportunities and outcomes. ${ }^{25}$ For example, gender quotas may target recruitment and selection procedures to ensure that women have equal opportunities from the start, such as in being able to run for elections. Likewise, gender quotas may go a step further and try to ensure that a certain proportion of women get elected. Such gender quotas can take the form of reserved seats, but they can also operate at the level of candidate selection by ensuring that female candidates are positioned in seats where they are likely to be elected. To frame the discussion within an even broader understanding of gender equality, Bacchi argues that debates on gender quotas need to challenge the representation of positive actions as 'special help' or 'preferential treatment'. Such portrayals suggest that existing social rules are fair, and that discrimination is incidental or limited to people who lack certain merits, rather than placing the focus on existing privileges and norms of dominant subjects. Problematizing the political privilege of men rather than the disadvantage of women, and highlighting the need for 'special' or 'preferential' measures, can help overcome a representation of women as problem holders or (paradoxically) favoured subjects, and a representation of men as the victims of unjust discrimination by gender quotas. In this alternative framing, gender quotas are understood as 'attempts to do justice' and 'redress entrenched

24 Emanuela Lombardo, Vlasta Jaluŝî̂, Maro Pantelidou Maloutas and Birgit Sauer, 'Taming the Male Sovereign? Framing Gender Inequality in Politics in the European Union and its Member States', in Mieke Verloo (ed.), Multiple Meanings of Gender Equality: A Critical Frame Analysis of Gender Policies in Europe (Budapest: CPS Books, 2007).

25 Petra Meier, 'Paritaire democratie: over een nieuw concept en oude wonden', Ethiek \& Maatschappij, Vol. 1, No. 4 (1998), pp. 9-23. 
privilege'. ${ }^{26}$ This understanding would place gender quotas within a broader gender equality and intersectional perspective, as it not only challenges male privilege, but also scrutinizes the extent to which gender quotas promote the increased representation of elite women in terms of class and ethnicity relative to other excluded groups of women.

To broaden the concept of gender equality and its intersections, feminist politics needs to consider how intersecting class, gender and race or ethnicity inequalities affect the 'politics of recognition' promoted by a gender quotas approach. According to Rai, recognition cannot be disentangled from Fraser's 'politics of redistribution', which is why gender quotas need to be part of a broader strategy that also includes a redistribution of socio-economic resources. Gender quotas in the South-Asian countries of Bangladesh, Pakistan and India highlight the importance of specific context analyses for assessing the impact of gender quotas for gender equality. ${ }^{27}$ Gender quotas need to be understood in context, being part of a complex picture where a multiplicity of political and socioeconomic factors play a role in the promotion of women's effective empowerment. Thus, a broader approach to equality also invokes attention to differences between women that emerge in specific contexts. We further tackle this issue when discussing the second shift.

In sum, gender quotas have shifted emphasis away from formal equality to a broader understanding of equal opportunities or equality of outcome, but not per se to a broader approach of intersectionality. Nonetheless, debates surrounding gender quotas have the potential to activate wider discussions about issues of inequality and privileges, thus further progressing the discussion.

\section{Can the use of gender quotas place gender equality and its intersections centre-stage?}

To address the extent to which gender has been placed centre-stage, it is imperative to consider the ways in which discussions on gender quotas have been addressed through the central institutions underpinning state order. The adoption of a number of gender quota measures has led to important debates on the concept of citizenship, representation, democracy and equality. The most notable example is perhaps the French parity debate, calling into question the universal character of French citizenship in order to replace it with the principle of parity. ${ }^{28}$ These debates led to a constitutional amendment

26 Carol Bacchi, 'Arguing For and Against Quotas: Theoretical Issues', in Dahlerup, Women, Quotas and Politics.

27 Nancy Fraser, 'From Redistribution to Recognition? Dilemmas of Justice in a " PostSocialist” Age', New Left Review, Vol. 212 (July-August 1995), pp. 68-93; Shirin M. Rai, The Gender Politics of Development: Essays in Hope and Despair (New Delhi: Zubaan; London: Zed Books, 2008).

28 Geneviève Fraisse, Muse de la raison: la démocratie exclusive et la différence des sexes (Aix-en-Provence: Alinea, 1989); Françoise Gaspard, Claude Servan-Schreiber and Anne Le Gall, Au pouvoir citoyennes! Liberté, égalité, parité (Paris: Seuil, 1992); Gisèle Halimi, La nouvelle cause des femmes (Paris: Seuil, 1997); Eléonore Lépinard, L'égalité introuvable: la parité, les féministes et la République (Paris: Les Presses de la Fondation nationale des 
enshrining the principle of gender equality - which reaches further than the former principle of non-discrimination - so as to create a legal basis for the adoption of statutory gender quotas. While the gender quotas adopted did not have much effect in terms of raising female numbers, they provoked a huge public debate on the social position of women.

However, such extensive debates have not taken place everywhere. In other European countries, discourses on this issue are gendered in the sense that the unequal roles of women and men in politics are made visible. However, one tends to discuss sex, in terms of the physical presence of women in politics opposed to men, rather than gender, which relates more to the socially constructed relations between women and men. ${ }^{29}$ Also, the adoption of gender quotas did not by definition lead to an explicit recognition of gender equality in constitutions or basic laws. In many cases, gender quotas were simply added to legislation regulating the organization of elections, such as in the first Belgian Gender Quotas Act of $1994 .{ }^{30}$ A constitutional amendment incorporating a parity clause was only included in the subsequent Gender Quotas Act 2002. In this sense, gender quotas do not necessarily put the concept of gender equality centre-stage, but eventually allow for more far-reaching initiatives on gender equality once such principles have been constitutionally embedded.

However, considerations of gender with other social inequalities such as ethnicity or class tend to be absent in official political discourse, and gender quotas do not tend to emphasize intersectionality. This primarily derives from the initial focus of gender quotas on specifically female under-representation in politics, and their use as a tool requiring the labelling of candidates by sex. In the French parity debate, however, the problem also flows from the rearticulation of the universal citizen into one person with both a male and a female face, based on the argument that men and women constitute the basic components of humanity. Advocates of parity democracy require that other inequalities are taken into account, since they cut across the category of sex, but this still leaves us far from an elaborate argument for intersectionality. It may even be the case that certain inequalities other than sex are disregarded altogether, perhaps justifying criticism that parity democracy advocates reproduce the universal concept of citizenship they want to change, by turning the universal asexual citizen into a universal man and a universal woman. Nonetheless, the rethinking of citizenship in official political discourse may bring the concept of equality to centre-stage because it still entails questioning the myth of universality. It might help to not only question the men-women divide, but also broader issues such as the increasingly multicultural character of many societies, and what such a trend involves for citizenship and the political rights attached to this status (such as the intrinsic link, in many cases, between political rights and nationality rather than place of residence and tax requirements). As Squires argues, 'given the growing

Sciences Politiques, 2007); Joan W. Scott, Parité! L'universel et la différence des sexes (Paris: Albin Michel, 2005).

29 Lombardo et al., 'Taming the Male Sovereign?'

30 Petra Meier, 'De kracht van de definitie: quotawetten in Argentinië, België en Frankrijk vergeleken', Res Publica, Vol. 46, No. 1 (2004), pp. 80-100. 
concerns about both intersectionality and multiple inequality strands, it may be time now for advocates of quota strategies to start thinking about whether, and how, these mechanisms might be reformulated to make them more sensitive to complex diversity, rather than simply sex difference'. ${ }^{31}$

Therefore, there is little empirical evidence so far that debates on gender quotas have moved the principle of gender equality to centre-stage. In many cases they seem to simply add rules to the processes of recruiting and selecting candidates. Furthermore, they do not facilitate an intersectional perspective.

\section{Can the use of gender quotas increase the number of women and pay attention to intersections of gender with other inequalities?}

This shift concerns the descriptive representation of women, and considers how effective gender quotas have been like a tool to increase the number of women in politics. As Dahlerup makes clear in her collective study on gender quotas, 'the mere introduction of quotas has not resulted in uniform increases in the numbers of women parliamentarians worldwide'. ${ }^{32}$ Others similarly report mixed results. ${ }^{33}$ In most cases the proportion of women elected does not equal the proportion of women candidates.

However, electoral gender quotas have the potential to increase women's representation rapidly, as Costa Rica or Rwanda have shown. ${ }^{34}$ Another frequently cited example is the Argentinean 'ley de cupos', which demonstrates how gender quotas can trigger an increase in the proportion of women elected if they exploit the electoral system. ${ }^{35}$ Gender quotas are thought to have more of an effect when they are implemented in proportional representation list systems using closed lists, by placing women in eligible positions with the help of placement mandates. High district or party magnitude is considered to be another critical success factor. ${ }^{36}$ However, findings are mixed. For instance, Schmidt and Saunders have found that the greatest gains in Peruvian local elections were found in districts with a low magnitude, where the relative magnitude of the largest party is of greater importance. This is due to the specificities of the electoral system, awarding the winning parties half plus one seat. In combination with gender

31 Squires, The New Politics of Gender Equality, p. 110.

32 Dahlerup, Women, Quotas and Politics, p. 18.

33 Krook, Quotas for Women in Politics; Bérengère Marques-Pereira and P. Nolasco (eds), La representation politique des femmes en Amérique latine (Paris: L'Harmattan, 2000); Franceschet et al., The Impact of Gender Quotas.

34 Dahlerup, Women, Quotas and Politics.

35 Clara Araújo and Ana Isabel García, 'Latin America. The Experience and the Impact of Quotas in Latin America', in Dahlerup, Women, Quotas and Politics.

36 Htun and Jones, 'Engendering the Right to Participate in Decision-Making'; Jones, 'Gender Quotas, Electoral Laws and the Election Of Women'; Jones, 'Electoral Institutions, Social Cleavages, and Candidate Competition'; Mark P. Jones and P. Navia, 'Assessing the Effectiveness of Gender Quotas in Open-List Proportional Representation Electoral Systems', Social Science Quarterly, Vol. 80 (June 1999), pp. 341-357. 
quotas and the fact that electoral lists are closed, the winning party tends to count at least one woman among its elected candidates. These women are placed in winnable positions even though the gender quotas legislation requires no placement mandates. ${ }^{37}$ The Argentinian Senate also illustrates that PR list systems and a large district magnitude are not necessary conditions for gender quotas to have an impact. The determining factor is the extent to which gender quotas are tailored to the features of the electoral system. In the Argentinian case, each constituency consists of three seats, two of which go to the winning party. Since parties have to rank a woman candidate on at least the second list position, winning parties send one man and one woman to the Senate. ${ }^{38}$

Successful gender quotas could be designed for (nearly) all types of electoral systems. Even in simple plurality systems, such as the British first-past-the-post system, seats could be twinned or double tickets could be introduced. Nonetheless, it remains valid that gender quotas are more easily added to some electoral systems than to others. For instance, the majority systems of an alternative vote or of a second ballot do not facilitate the implementation of gender quotas. However, the main point remains that in order to be successful, gender quotas must exploit the unique possibilities of different electoral systems.

A second major prerequisite for gender quotas to achieve an increase in the proportion of women elected is the extent to which they force parties to put women in eligible positions. Even statutory gender quotas do not necessarily guarantee a result, as is well illustrated by the French case. At the first elections following the adoption of gender quotas, the share of women elected to the National Assembly rose from 11 per cent to 12 per cent. Parties could evade gender quotas by accepting a financial penalty, such as losing a minor share of their first slice of state subsidies. Since the bulk of a party's state subsidy depends on electoral results, major parties offset a loss of their first slice by winning the elections with male incumbents. ${ }^{39}$ Spain introduced a legal requirement that each sex constitutes no less than 40 per cent and no more than 60 per cent of each group of five candidates: this led to a small increase in the number of women elected relative to percentages formerly achieved through gender quotas introduced by left-wing parties. Parties tend to assign women the lowest proportion of the candidature ( 40 per cent) and to place men in the higher ranks of the top five list positions. ${ }^{40}$ Rather than good faith compliance, it is the compulsory nature of gender quotas and the introduction of 'zipper systems ${ }^{41}$ that make parties place women in eligible positions.

37 Schmidt and Saunders, 'Effective Quotas, Relative Party Magnitude, and the Success of Female Candidates'.

38 Meier, 'De kracht van de definitie'.

39 Rainbow Murray, 'Why Didn't Parity Work? A Closer Examination of the 2002 Election Results', French Politics, Vol. 2, No. 3 (2004), pp. 347-362.

40 Tània Verge, 'Gendering Representation in Spain: Opportunities and Limits of Gender Quotas', Journal of Women, Politics and Policy, Vol. 31, No. 2 (2010), pp. 166-190.

41 'Zipper quotas' are provisions requiring that a certain percentage of women are placed in eligible positions on the candidate list, for example every other place goes to a women, to ensure that a certain number of women will be elected. See www.idea.int/publications/ designing_for_equality/quota_definitions.cfm. 
Intersectionality remains important; gender quotas have been criticized for not taking into account differences between women, thereby reproducing dynamics of domination and exclusion among them. ${ }^{42}$ The case of Belgium, however, demonstrates intersectionality at work: gender quotas not only tend to bring more women into parliament, but on average these women are also younger than their male colleagues, and many have a foreign background. The required focus on sex diversity in selection processes has also enabled parties to broaden their scope. However, the ideal of the white middle-class candidate remains firmly entrenched. ${ }^{43}$

In conclusion, gender quotas have had limited success in increasing the descriptive representation of women, and their design does not typically pay much attention to intersections of gender with other inequalities.

\section{Can the use of gender quotas lead to an adjustment of structures, procedures and tools?}

Feminist literature on gender inequality in politics frequently considers obstacles to women's equal political representation arising from structural factors, such as the nature of electoral systems, ${ }^{44}$ political parties, ${ }^{45}$ and the 'deeply embedded culture of masculinity' in institutional structures. ${ }^{46}$ Both the introduction of gender quotas and the debates around them have placed an emphasis on structural transformations such as changing electoral rules, increasing party magnitude, or modifying the composition of electoral lists so that women candidates occupy more and better positions. This has shifted the discussion from a 'supply-oriented approach' (why do women (not) run for office?) to a 'demand-oriented approach' (why do parties (not) recruit women?). In turn, this has enabled the questioning and reforming of political structures and procedures to facilitate women's entry in political institutions.

Therefore, the adoption of gender quotas has led to the adjustment of structures and procedures to some extent, but not profoundly. For instance, the 2002 Belgian Gender Quotas Act required gender equality in all electoral lists, as well as in the two top positions of each list. However, the candidate heading the list is entitled to more campaign money than other candidates. Thus, while the placement mandate opens one of the two top positions to women, the regulations on campaign spending still create a difference between the first and second position on the list. In order to change structures and procedures, such specific rules of the electoral system also need to be tackled when designing gender quotas.

42 Rai, The Gender Politics of Development.

43 Silvia Erzeel and Petra Meier, 'Is er iets veranderd? De rekrutering en selectie van kandidaten door Belgische partijen na de invoering van quotawetten', Tijdschrift voor Genderstudies, Vol. 14, No. 2 (2011), pp. 6-19.

44 Monique Leyenaar, Political Empowerment of Women: The Netherlands and Other Countries (Leiden: Martinus Nijhoff, 2004).

45 Joni Lovenduski and Pippa Norris, Political Recruitment: Gender, Race and Class in the British Parliament (Cambridge: Cambridge University Press, 1995).

46 Joni Lovenduski, Feminizing Politics (Cambridge: Polity, 2005), p. 48. 
Also, examples from the EU, the Netherlands and Spain reveal a limited capacity to challenge the deeply ingrained sexism of existing institutional cultures. ${ }^{47}$ Since the main framing of the gender inequality problem in politics has to do with women's numbers, frames that tackle some of the structural causes of the problem, such as the traditional gendered division of labour or the existence of patriarchal relations in different spheres of society, tend to remain in the shade. This limits the possibility of challenging the existing gender bias present in political structures and procedures that is based on 'unspoken assumptions about a traditional gendered division of labour'. ${ }^{48}$

Other cases confirm this, even where gender quotas have been implemented. In Belgium, years after the adoption of gender quotas, male politicians still do not consider the under-representation of women in politics to be a problem. They see no discrimination and consider it a matter of difference in individual choice between men and women. According to female politicians, however, the causes of women's under-representation are to a large extent found at a more structural level. This difference between men and women reflects a different attitude towards the consideration of gendered thresholds and dynamics in the processes of recruitment and selection. ${ }^{49}$ So long as gender quotas do not go hand in hand with changing the gender biases of recruitment and selection processes, they will probably not have a lasting effect. In this respect, Bjarnegard and Zetterberg argue that gender quotas which contribute to changing rules, practices and norms will more successfully balance gender relations than other types of gender quotas. ${ }^{50}$

In sum, debates on gender quotas bring structures and processes into question, but this exercise is often superficial. As long as the functioning of political institutions or recruitment procedures are not profoundly questioned from a gender perspective, there is little chance that gender quotas will have a lasting effect.

\section{Can the use of gender quotas lead to the creation of spaces for gender contestations and women's empowerment?}

There is some evidence that debates on gender quotas have given space to contestation, and enabled the creation of alliances and empowering triangles. One such case is Brazil, where debates on gender quotas are an occasion for both contesting the inequality of political power and forging women's alliances. Another is France, where debates on parity democracy has led to a broad mobilization of alliances among women. ${ }^{51}$

47 Lombardo et al., 'Taming the Male Sovereign?

48 Lovenduski, Feminizing Politics, pp. 146-147.

49 Petra Meier, 'A Gender Gap Not Closed by Quotas: The Renegotiation of the Public Sphere', International Feminist Journal of Politics, Vol. 10, No. 3 (2008), pp. 329-347.

50 Elin Bjarnegard and Pär Zetterberg, 'Removing Quotas, Maintaining Representation: Overcoming Gender Inequalities in Political Party Recruitment', Representation, Vol. 47, No. 2 (2011), pp. 187-199.

51 Lépinard, L'égalité introuvable; Teresa Sacchet, 'Beyond Numbers. The Impact of Gender Quotas in Latin America', International Feminist Journal of Politics, Vol. 10, No. 3 (2007), pp. 369-386. 
In the EU and some of its member states, the importance of creating 'velvet triangles' between state feminists, party women and feminist activists is highlighted in the discourses of gender experts and civil society actors. Such discourses address the role of women's policy agencies, as well as politicians and their cooperation with civil society and women's movements. The main ideas of these discourses relate to the importance of establishing women's institutional bodies (such as ministries, councils, advisory boards, committees or equal opportunities offices) or of increasing the power and competencies of existing gender equality agencies. Discussion also centres on the need for stronger cooperation between gender equality agencies and civil society organizations: in particular, they focus on the strengthening of women's movements and women in decisionmaking networks, with the aim of creating triangles of empowerment between women situated in both formal and informal politics. However, these discourses, as well as the actors voicing them, are seldom mentioned in official policy documents promoting gender equality in politics. They nonetheless demonstrate that broader discussions on strategic political alliances among women take place in the political arena. If reinforced, they could promote more transformative gender equality policies regarding the redistribution of gender roles, the challenging of gender privilege and the intersection of gender with other inequalities. ${ }^{52}$

\section{Conclusion}

This article began with a plea to reintroduce discussion of gender relations in politics back into scholarly and political debates. Many countries worldwide have adopted gender quotas, but it is unclear whether their implementation has meaningfully changed inequalities prevailing in gender relations in politics. This article considers whether the implementation of gender quotas could promote change based on five quality shifts that have been identified in assessing the implementation of gender mainstreaming. These are a shift towards a more comprehensive concept of gender equality (shift 1); the incorporation of a gender perspective intersected with other inequalities in mainstream politics (shift 2); equal political representation (shift 3); organizational changes in selection and recruitment mechanisms, as well as the functioning of politics (shift 4); and, finally, the displacement of hierarchies and the empowerment of subjects (shift 5). Incremental progress from the status quo ante has been considered in exploring each criterion. This paper has queried whether the implementation of gender quotas could contribute to the achievement of these criteria, and has argued that gender quotas could be a best practice of gender mainstreaming, rather than being a completely separate strategy to achieve gender equality. However, reflection on and empirical illustrations of gender quotas with regard to these criteria reveal a mixed picture. The use of gender quotas per se does not necessarily generate a shift towards a broader approach to gender and intersectionality (shift 1), but debates on gender quotas can generate wider discussions about inequality, demonstrating the need to reintroduce discussions about gender equality within politics back into gender quota debates. This discussion should not focus

52 Lombardo et al., 'Taming the Male Sovereign? 
on the legitimacy of or need for gender quotas, but on how their implementation can contribute to the improvement of gender relations in politics beyond a quantitative sense. Approaching gender quotas on the basis of the quality criteria devised for assessing gender mainstreaming is helpful in exploring their potential. Two conditions for fostering a broader conceptualization of gender and intersectionality are apparent: first, the articulation of policy debates which challenge privileges stemming from gender, class, ethnicity or other identities; and, second, the responsiveness of state policy actors to gender quota debates in the multiple contexts in which they are relevant. Both call for a shift in the conceptualization of gender quotas, emphasizing the need to question existing privileges (related to gender and other inequalities), and a change in the perception of gender quotas by women and men. Within the political arena, debates on gender quotas have not necessarily put the concept of gender equality centre-stage by relating it to concepts like citizenship, democracy and representation (shift 2), but this is theoretically possible.

Gender quotas have helped to increase the number of women in politics but do not focus on intersectionality (shift 3), although this is a limitation of gender mainstreaming as well. Thus, gender quotas need to become outcome-oriented and receptive to considerations of diversity beyond sex in institutions of political decision-making. Gender quotas may lead to some adjustment in structures and procedures (shift 4), as their use requires the reorganization and change of institutions and electoral rules, but this does not necessarily impact upon existing (sexist) cultures. Therefore, organizational change would need to be linked with a more general debate about gender inequality and privileges in political institutions. This would require an analysis of gender biases in recruitment and selection processes, as well as in the functioning of the political arena more broadly. We found some evidence that the adoption of gender quotas allowed for spaces of contestation and the creation of alliances and empowering triangles. Debates on gender quotas have to some extent involved feminist activists and experts through the creation of networks (shift 5), but the voice of feminist activists and gender experts in official policy texts on gender inequality in politics is still limited. The role of velvet triangles of cooperation between such women as state feminists, politicians and activists is still small and could be strengthened to increase the possibility of more transformative frames in terms of gender roles.

We should underline that we have conceptualized the potential of gender quotas rather than empirically testing their precise impact in a given context throughout this analysis. The latter would involve a more stringent research design, involving control for other factors contributing to the shifts explored above. The mixed results coming out of this reflection may perhaps be countered by the fact that gender mainstreaming efforts in practice do not contain such a transformative potential. Why set the bar so high if gender mainstreaming policies often do not meet such requirements? When it comes to designing concrete policies, one might perhaps consider what constitutes a realistic goal. However, when it comes to the potential of gender quotas to change gender relations in politics - or indeed, the transformative potential of any other policy tool - it is useful to set the bar high. Doing so opens perspectives, points out potential weaknesses, and highlights room for action and change.

The mixed results of gender quotas in promoting a transformation of existing inequalities in politics demonstrate that it is worthwhile bringing discussions about 
gender equality within politics back into debates on gender quotas. Discussion should therefore not focus on whether or not gender quotas are needed or legitimate, but on whether they can improve gender relations in politics beyond balancing the numbers. Approaching gender quotas with reference to the quality shifts gender mainstreaming is meant to provoke is thus helpful in defining their potential, since such shifts identify a number of minimum conditions under which gender quotas could be qualitatively successful. Thus, this article also suggests that gender mainstreaming and gender quotas are not merely two parallel and independent strategies to promote gender equality - nor that one could replace the other. While gender quotas do not seem to be a best practice of gender mainstreaming, this article demonstrates that considering one strategy in light of another yields insights into how it may be strengthened.

\section{Author biographies}

Emanuela Lombardo is Lecturer in Political Science at Madrid Complutense University. She has undertaken research on different European and Spanish projects on gender and politics. She works on gender equality policies in Europe, especially in the European Union and Spain, the Europeanization of equality policies, and gender and political representation. She has recently co-edited The Europeanization of Gender Equality Policies (with Maxime Forest, 2012) and The Discursive Politics of Gender Equality (with Petra Meier and Mieke Verloo, 2009).

Petra Meier is Associate Professor in Political Science and Director of the Policy Research Centre on Equality Policies at the University of Antwerp. Her research and publications focus on issues of representation in politics and policies. She recently co-edited (with Jill Vickers and Louise Chappell) a special issue of Publius: The Journal of Federalism on gender approaches to federalism studies (Vol. 43, No. 1, 2013). Currently, she is working on a book on the symbolic representation of gender (with Emanuela Lombardo). 